\title{
Electrospinning of Metal Doped Alumina Nanofibers for Catalyst Applications
}

\author{
Sneha Swaminathan and George Chase \\ The University of Akron, \\ USA
}

\section{Introduction}

The world is turning into a vast technological jungle and the amount of pollution has increased proportionally to the number of industries and world population. The majority of the pollution is created by anthropogenic activities that include burning of fossil fuels, exhaust of automobiles and other combustion processes. Beginning with the 1940s, some urban cities started experiencing air pollution because of the increasing number of automobiles (HaagenSmit, 1970). By the 1960s, cars had been manufactured in large quantities and had become popular in providing personal mobility to an increasing range of people. But in automobiles, the process of combustion of gasoline in the engine to carbon dioxide $\left(\mathrm{CO}_{2}\right)$ and water was not a very efficient process (Twigg, 2007). The byproducts of combustion include residual uncombusted hydrocarbons (HCs), partial combustion product carbon monoxide (CO), nitric oxides $\left(\mathrm{NO}_{\mathrm{x}}\right)$ formed from atmospheric nitrogen during combustion, and particulate matter (PM), especially carbonaceous particulate formed in diesel engines (Shelef \& McCabe, 2000). In the engine exhausts the $\mathrm{CO}$ level ranged from 1 to 2 vol. \% while unburnt HCs ranged between 500- $1000 \mathrm{vppm}$. During the process of combustion, very high temperatures are produced by the burning of gasoline droplets that result in the thermal fixation of $\mathrm{N}_{2}$ in the air to form $\mathrm{NO}_{x}$ with concentrations in the range of 100-300 vppm (Patterson\& Henein,1972; Armor, 1994; Heck \& Farrauto, 1995; Silver et al., 1992). $\mathrm{NO}_{x}$ (where $1<\mathrm{x}<2$ ), consisting mainly of nitrogen monoxide (NO) and nitrogen dioxide $\left(\mathrm{NO}_{2}\right)$ are one among many toxic pollutants in air. NO is the most abundant nitrogen derivative present in the atmosphere, and represents $95 \%$ of the total $\mathrm{NO}_{\mathrm{x}}$ emissions (Degobert \& Marshall, 1995). The total nitrogen oxides emitted in the world from automotive exhausts was 6.4 million in 2005 (EPA,2005). $\mathrm{NO}_{\mathrm{x}}$ undergoes photochemical reactions leading to the generation of smog. It has been proven to cause serious health impacts such as respiratory troubles, circulation problems, and premature death (Patterson\& Henein,1972; Meulenbelt, 2007). Another major pollutant is carbon monoxide. CO poisoning is the most common type of fatal poisoning in many countries. $\mathrm{CO}$ adversely effects human health leading to cardiovascular and neurobehavioral problems, developmental disorders and in some cases even death (Raub et al., 2000). CO primarily occurs in urban traffic where gasoline engines often idle resulting in high concentration levels of up to $100 \mathrm{mg} / \mathrm{m}^{3}$ (Degobert \& Marshall, 1995).

To prevent environmental pollution, it is essential to eliminate these toxic air pollutants by converting them into less harmful substances. Hence their abatement using catalysts is a very important topic of research and application. Noble metals are most commonly used as 
catalysts for reducing these air pollutants and to meet the stringent federal regulations (Patterson \& Henein, 1972) The global market for energy and environmental catalysts was worth $\$ 12.2$ billion in 2006, \$13.0 billion in 2009 and an estimated $\$ 18.5$ billion in 2012 at a compound annual growth rate (CAGR) of $7.4 \%$ from 2007 to 2012 (BCC Research, 2007).

Noble metals can be used as nanocatalysts to eliminate these toxic substances from the various exhausts. Nanosize materials possess high surface energy which result in specific catalytic activity and selectivity (Zhou et al., 2004). The catalytic activity of supported metal particle catalysts is strongly dependent on the size and shape of the particles. Hence, on a mass basis nanocatalysts are very active due to their high surface areas and high specific catalytic activity (Gai et al., 2002). Nanocatalysts also optimize the use of precious metals thus minimizing the specific cost per function.

Due to high surface area to volume ratio, noble metal nanoscale metals differ in their properties from bulk materials (Narayanan \& El-Sayed, 2005). These materials have potential applications in catalysis and as sensors (Takashi et al.,2005). Supported nanoparticles have been used for a variety of heterogeneous catalysis reactions such as acylation, alkane isomerisation, benzene hydrogenation, Suzuki-Miayura reaction and Heck's reaction. Nanoparticles have properties in between bulk materials and molecules and are potentially useful for new generations of chemical, optical, magnetic, and electronic devices. Well distributed nano sized noble metal particles show better potential as catalysts than bulk materials [Gniewek et al., 2008; Luo et al., 2005; . Tribolet \& Kiwi-Minsker, 2005). Metal oxide nanofibers are potential candidates as catalyst supports for heterogeneous catalytic reactions (Patel et al., 2007; Park et al., 1998; Park et al.,2008). Nanofibers can be produced by electrospinning. Electrospinning is a process in which fibers of nanoscale or submicron scale are generated, as the electrified jet (composed of a highly viscous polymer solution) is continuously stretched due to electrostatic repulsions between the surface charges. The jet continues to stretch until it either encounters a grounded surface or enough of the solvent has evaporated that the jet is no longer fluid enough to stretch ( $\mathrm{Li} \& \mathrm{Xia}$, 2004). The fiber diameter can be controlled by varying the process parameters such as polymer concentration, viscosity, electric field, solvent composition, flow rate, diameter and angle of spinneret (Doshi \& Reneker, 1995). As catalyst supports, nanofibers can provide a means of constructing catalytic systems that have large surface area, are lightweight, are thermally and chemically stable, and result in optimization of precious metals (Takashi et al., 2005). The formation of nanoscale diameter fibers from electrospinning have been explored for high-performance filters, wound dressing materials, and biomaterial scaffolds for tissue engineering (Wei \& Ma, 2004; Filatov, 2007). The structures thus produced have a high surface area to volume ratio, high length to diameter ratio, high porosity and interconnected pores, good surface functionalities, and superior mechanical performance (e.g. stiffness and tensile strength) (Doshi \& Reneker, 1995; Sukigara et al., 2003; Huang et al., 2003). Figure 1 shows the schematic diagram of an electrospinning setup.

Traditionally, the catalysts are coated onto commercial monolithic supports by the wetness impregnation technique. In this method, the catalyst precursor salt is dispersed on the support surface by the impregnation of the solution of the precursor. The precursor particles are formed in the drying process, calcined to form metal-oxides and subsequently reduced to form fine supported metal particles (Zhou et al., 2004).

In the present work, an alternative approach has been developed wherein the noble metal nanocatalysts are incorporated into a ceramic nanofiber. The catalysts on ceramic nanofibers increase the overall exposed catalyst area and simultaneously immobilize the catalyst to 


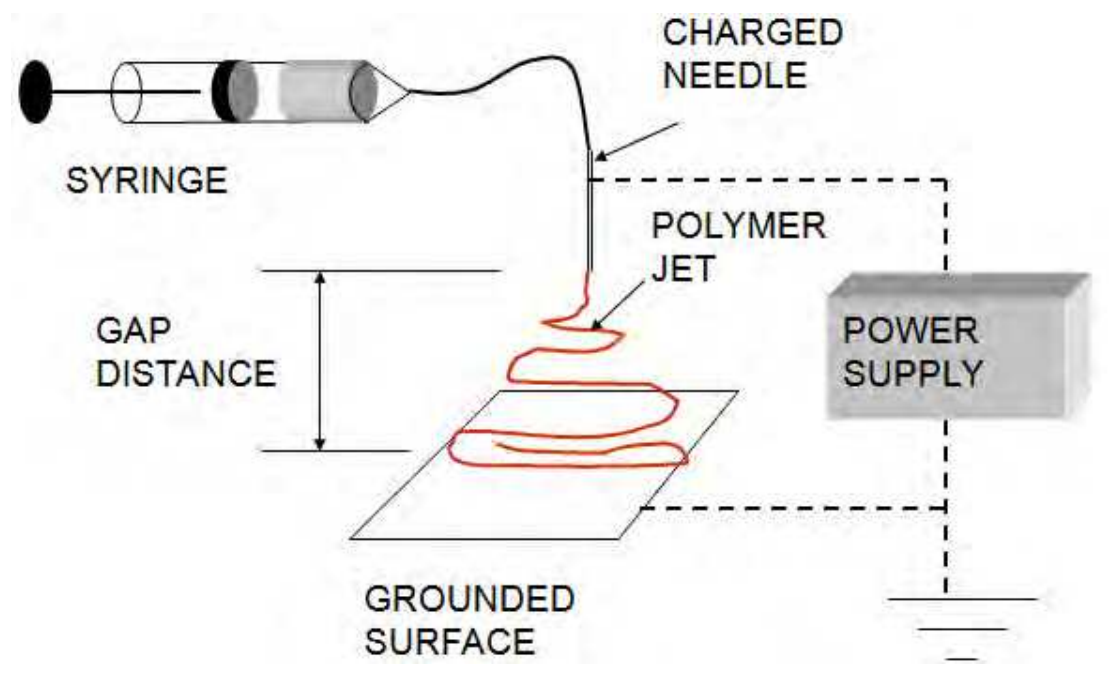

Fig. 1. Electrospinning setup.

minimize catalyst loss. A small amount of the catalyst incorporated ceramic nanofibers are mixed with microfibers to fabricate a filter disk by a vacuum molding technique. This filter disk, termed as 'catalytic filter', is a combination of catalytic elements and filter. The catalyzed ceramic nanofiber augmented microfiber filter media can be used for two applications: reduction of $\mathrm{NO}_{x}$ and oxidation of $\mathrm{CO}$ and for enhanced particulate removal. This chapter describes the process of fabrication of the catalytic filters and its applications in reducing $\mathrm{NO}_{x}$ and $\mathrm{CO}$ emissions.

The combination of two operations, catalysis and filtration, in one operation improves performance and reduces processing, investment and maintenance costs (Heidenreich et al., 2008). The individual nanoparticles are dispersed throughout the entire fiber and firmly anchored to the walls of the pores of the alumina support; hence their tendency to sinter and coalesce is minimized. In addition, there is free diffusional access of reactants and exit of products from the nanocatalyst, thereby facilitating the catalytic turnover of bulky organic molecules such as unburnt hydrocarbons (Hermans et al., 2001; Raja et al., 2001; Thomas et al., 2001). Nanomaterials are more effective than the monolithic support structures for two reasons. First, their extremely small size yields a tremendous surface area-to-volume ratio. Second, when materials are fabricated on the nanoscale, they achieve properties not found within their macroscopic counterparts. Both of these reasons account for the versatility and effectiveness of nanocatalysts. They also help in reducing the cost of processes which are indispensable without them (Schlogl \& Hamid, 2004).

Fibrous materials in filter media have advantages which include high filtration efficiency and low air resistance (Tsai et al., 2002). One method to develop highly effective and efficient filters is by the addition of nanofibers. When the channels and structural elements of a filter are matched to the size of the particles or droplets to be captured, the capture efficiency improves considerably (Graham et al., 2002). Nanofibrous media have low basis weight, high permeability and small pore size that make them appropriate for a wide range of filtration applications. Nanofibers offer unique properties of high specific surface area, high porosity and good interconnectivity of pores, potential to incorporate active chemistry 
or functionality on nanoscale and high permeability for gases (Barhate \& Ramakrishna, 2007; Ahn et al., 2006). The nanofibrous media have advantages over mesoporous media by avoiding the mass transfer limitation of substrates due to reduced thickness and intrafiber porosity. In particular, they are highly successful for the development of high-performance air filters. The electrospinning process in particular can be used to tailor the porosity, fiber diameter, and pore size to achieve the desired structural configuration (Barhate \& Ramakrishna, 2007).

From filtration theory, submicron fibers have better filter efficiency than larger fibers at the same pressure drop in the interception and inertial impaction regimes. The interception and inertial impaction efficiencies will increase faster, more than compensating for the pressure drop increase (Graham et al., 2002). A second factor for submicron fibers is the effect of slip flow on the fiber surface. One assumption in filtration theory is that of continuous flow around the fiber with no-slip condition at the fiber surface. But, when the scale of the fiber becomes small enough that the molecular movements of the air molecules are significant in relation to the size of the fibers and the flow field, this assumption becomes invalid and slipflow model is added to extend the filtration theory.

\section{Experimental: fabrication of catalytic filters}

The manufacture of the catalytic filter media involves the steps shown in Fig.2. The active ingredient in the catalytic filter is the ceramic nanofibers i.e. metal incorporated alumina nanofibers which is responsible for the conversion of $\mathrm{NO}_{\mathrm{x}}$ and $\mathrm{CO}$ into safer products.

Over the years, ceramic nanofibers have evolved with a multitude of applications which can be categorized primarily in four ways (Ramaseshan et al., 2007):

1. Chemistry based applications: catalysis, storage batteries, membranes, fuel cells, sensors,

2. Physical change based applications: optical communications, data and magnetic storage,

3. Materials based applications: filtration, paints, packaging, aerospace, and

4. Biomedical applications: biosensors, bone and tissue engineering, biomechanical devices

Hence, in this research the immense potential of ceramic nanofibers is exploited for catalysis and filtration applications.

The main steps in the fabrication of a catalytic filter are:

1. Preparation of the electrospinning solution,

2. Electrospinning to form metal oxide incorporated alumina nanofibers,

3. Vacuum molding to form fibrous filter, and

4. Reduction to convert the catalyst metal oxides in the alumina nanofibers to their catalytic metal state.

The synthesis of ceramic nanofibers involves three main steps:

1. Preparation of sol with suitable inorganic precursor and carrier polymer with suitable concentration, mixing and temperature conditions,

2. Electrospinning the sol by adjusting and optimizing conditions such as viscosity, electric field, concentration, flow rate etc. to obtain composite fibers, and

3. Calcination of the composite mat to decompose the polymer template and to convert the metal precursors to their respective oxides. 


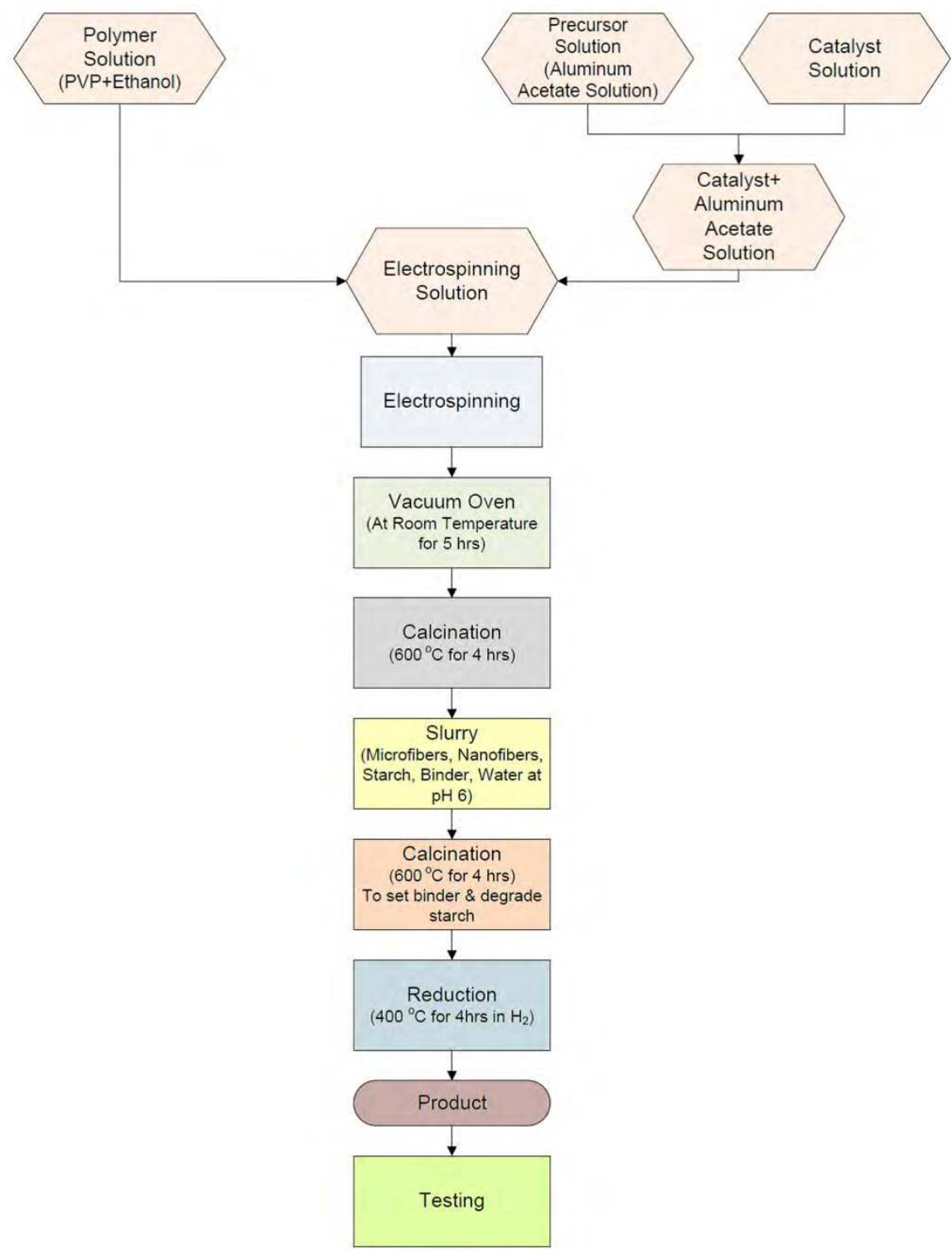

Fig. 2. Process flow diagram for the manufacture of catalytic filter.

The purposes of a carrier polymer are to assist with the electrospinning process and to form uniform colloidal dispersions of catalyst salt particles (Esumi et al., 1994). In this case, polyvinylpyrrolidone (PVP) was chosen as the carrier polymer because PVP can form a complex with the metal ions or metal particles, which can prevent the agglomeration of the cluster, and synthesis monodisperse nanoparticles with uniform size (Qian et al., 2001). PVP also plays an important role in protecting and stabilizing the colloidal dispersions of noble 
metals. Since soluble polymers can cover the whole surface of the catalyst, the effect of the supporting polymer may be promoted in the case of the polymer- protected colloidal metals compared with that by inorganic supports (Hirai et al., 1985). The precursor for alumina is basic aluminum acetate. The oxidation of basic aluminum acetate produces alumina. Aluminum acetate is calcined in air at $600{ }^{\circ} \mathrm{C}$ to form alumina. At this temperature, the carrier polymer degrades primarily to $\mathrm{CO}_{2}$ and $\mathrm{H}_{2} \mathrm{O}$. The stepwise conversion is as follows: From 170 to $220^{\circ} \mathrm{C}$, condensation of the $\mathrm{OH}$ groups on the basic acetate occurs by the reaction (Ayral \& Droguet, 1989).

$$
2 \mathrm{Al}(\mathrm{OH})(\mathrm{OAc})_{2} \longrightarrow \mathrm{Al}_{2} \mathrm{O}(\mathrm{OAc})_{4}+\mathrm{H}_{2} \mathrm{O}
$$

From, 220 to $475{ }^{\circ} \mathrm{C}$ the two carboxylates groups decompose to form amorphous alumina. Other phases of the alumina can be obtained by calcining at higher temperatures (Ayral \& Droguet, 1989). This is described by the reaction

Amorphous $\mathrm{Al}_{2} \mathrm{O}_{3} \stackrel{800^{\circ} \mathrm{C}}{\longrightarrow} \mathrm{\gamma Al}_{2} \mathrm{O}_{3} \longrightarrow \mathrm{\delta Al}_{2} \mathrm{O}_{3} \longrightarrow \mathrm{AAl}_{2} \mathrm{O}_{3} \stackrel{1200^{\circ} \mathrm{C}}{\longrightarrow} \mathrm{a} \mathrm{Al}_{2} \mathrm{O}_{3}$.

\subsection{Electrospinning of palladium doped alumina nanofibers}

To optimize the electrospinning process, combinations of several parameters have to be considered. 9 wt. \% solution of polyvinylpyrrolidone (PVP, Aldrich, $\mathrm{M}_{\mathrm{W}}$ 1,300,000) in ethanol (Pharmco-AAPER alcohol) was prepared. This molecular weight of PVP was used because low concentrations of PVP could be used for electrospinning when diluted with ceramic precursor solution to obtain nanofibers with small diameters. Since the carrier polymer is generally sacrificed in the end to obtain ceramic nanofibers, lower concentrations of the polymer are preferred to increase the yield of ceramic nanofibers. Aluminum acetate precursor solution (AA solution) was prepared by mixing aluminum acetate (Alfa Aesar, Basic hydrate), water and formic acid in the weight ratio of 1:2.5:1, respectively. The PVP solution and AA solution were mixed in the weight ratio of 1:2, respectively. Palladium chloride (Sigma-Aldrich, $60 \% \mathrm{Pd}$ ) was mixed in the resulting mixture in the ratio of $5 \mathrm{wt} \%$ $\mathrm{PdCl}_{2}$ with respect to aluminum acetate and stirred overnight at $40{ }^{\circ} \mathrm{C}$ using a magnetic stirrer. The solution was further diluted with ethanol. The solution was electrospun with a flow rate of $2 \mu \mathrm{l} / \mathrm{min}$ and an electric field of $1 \mathrm{kV} / \mathrm{cm}$. The sample was placed in a vacuum oven at room temperature for 5 hours to remove trapped solvents. The electrospun nanofibers were calcined to $600{ }^{\circ} \mathrm{C}$ to degrade the polymer and convert the metal precursors to metal oxides. From Thermogravimetric Analysis (TGA) there was significant mass loss as the temperature was ramped up to $500{ }^{\circ} \mathrm{C}$. Above $500^{\circ} \mathrm{C}$, the sample mass became constant, indicating that the organic materials (PVP, ethanol, acetate group) had degraded and the volatiles had evaporated (Figure 3). Hence, the fibers calcined to $600{ }^{\circ} \mathrm{C}$ were relatively pure metal oxide and free of PVP and residual solvent.

To obtain the fiber diameter distribution, the diameters of 100 fibers were measured from 10 Scanning Electron Microscope (SEM) images similar to those in Figure 4. The distribution was calculated using Equations (1) and (2) (Dosunmu et al., 2006; Varabhas et al., 2008):

$$
\begin{gathered}
\ln \left(\overline{x_{g}}\right)=\frac{1}{L_{t}} \sum L_{i} \ln \left(x_{i}\right) \\
\ln \left(\sigma_{g}\right)=\sqrt{\frac{\sum\left(L_{i}\left(\ln \left(x_{i}\right)-\ln \left(\overline{x_{g}}\right)\right)^{2}\right)}{L_{t}}}
\end{gathered}
$$


where, $\mathrm{L}_{i}$ is the length of the fiber segments with diameter $x_{i}$ and $L_{t}=\sum L_{i}$. The distributions are asymmetric and may be fitted with a log-normal distribution.

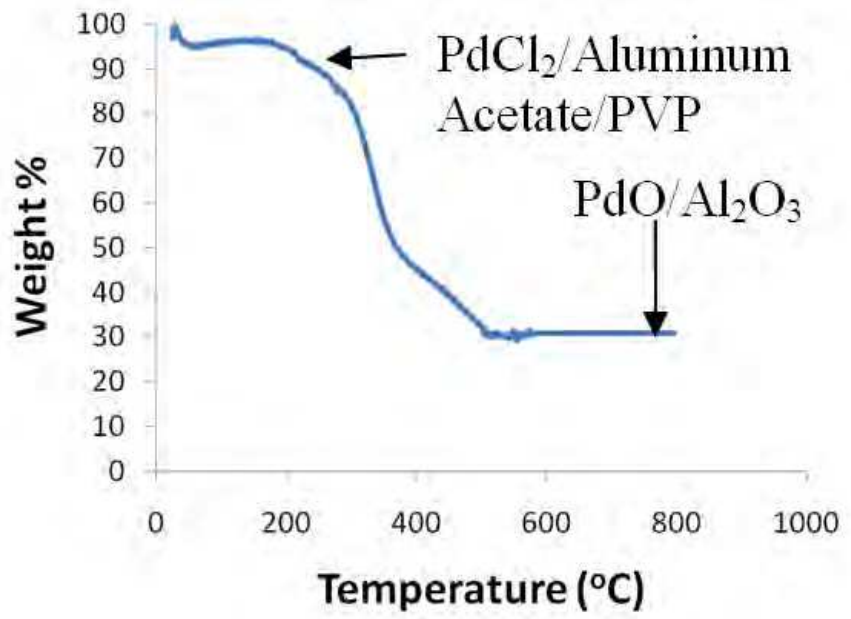

Fig. 3. TGA of $\mathrm{PdCl}_{2}$ / Aluminum Acetate/PVP nanofibers.
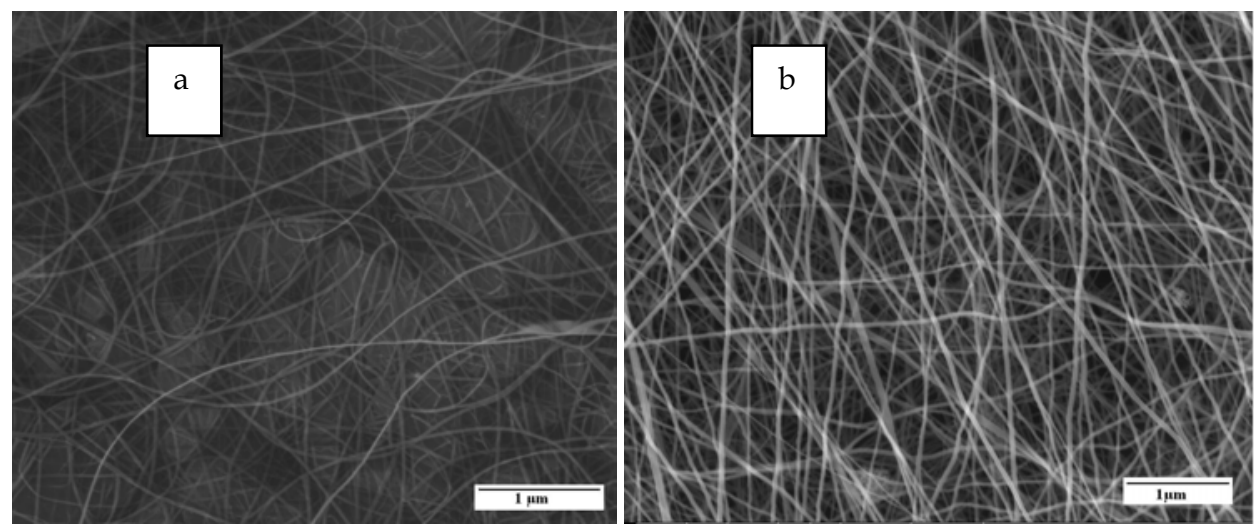

Fig. 4. SEM images of (a) $\mathrm{PdCl}_{2}$ / Aluminum Acetate/PVP nanofibers and (b) $\mathrm{PdO} / \mathrm{Al}_{2} \mathrm{O}_{3}$ nanofibers.

The frequency distributions are determined from Equation (3)

$$
f_{i}=\frac{1}{d_{i}} \frac{1}{\ln \sigma_{g} \sqrt{2 \pi}} \exp \left(-\frac{\left(\ln \left(x_{i}\right)-\ln \left(\overline{x_{g}}\right)\right)^{2}}{2\left(\ln \sigma_{g}\right)^{2}}\right)
$$

and plotted in Figure 5. The average fiber diameter was $\overline{\mathrm{x}_{\mathrm{g}}}=54.59 \mathrm{~nm}$ and standard deviation was $\sigma_{g}=1.28$ for the log-normal distribution. 


\section{Frequency Distribution vs Fiber Diameter}

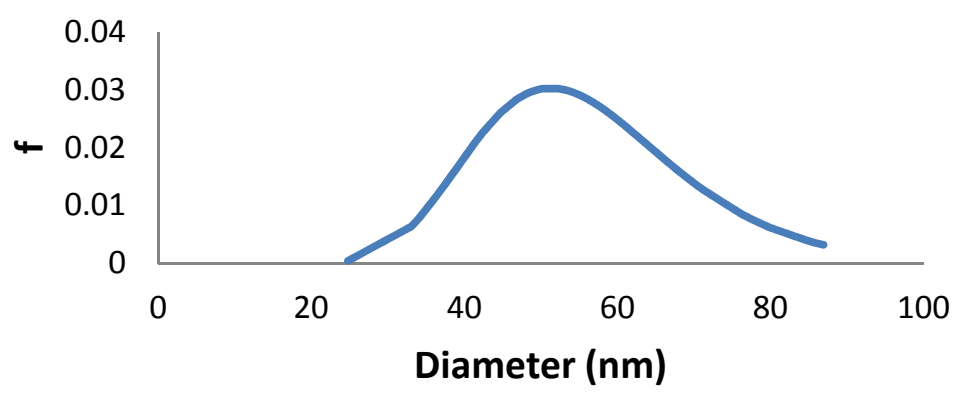

Fig. 5. Length weighted log-normal frequency distribution of $\mathrm{PdO} / \mathrm{Al}_{2} \mathrm{O}_{3}$ fiber diameters.

From Transmission Electron Microscope (TEM) images (Figure 6) the average particle size of 50 measurements of the $\mathrm{PdO}$ nanoparticles on the $\mathrm{Al}_{2} \mathrm{O}_{3}$ nanofiber was $2.43 \pm 0.70 \mathrm{~nm}$.

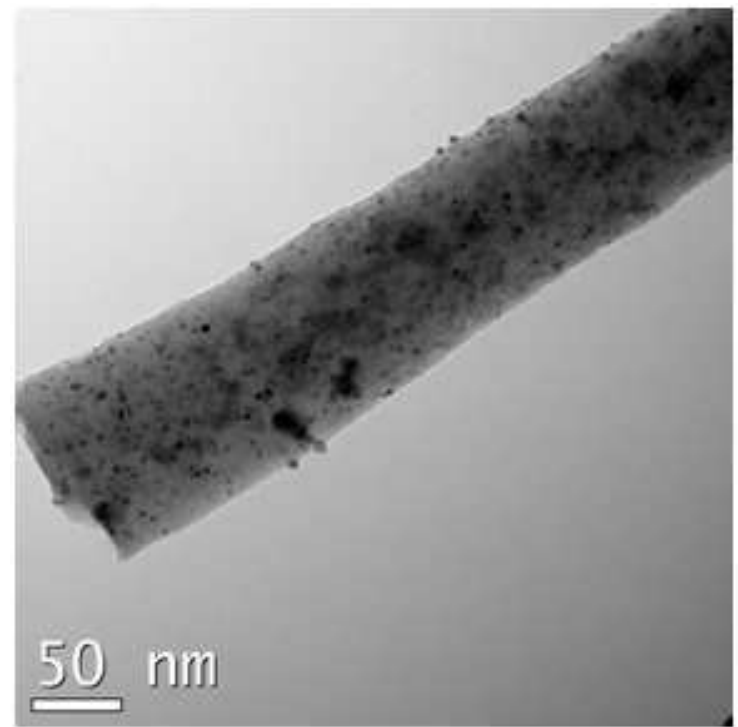

Fig. 6. Transmission electron micrographs of $\mathrm{PdO} / \mathrm{Al}_{2} \mathrm{O}_{3}$ nanofibers. 


\subsection{Electrospinning of platinum incorporated alumina nanofibers}

The 9 wt. \% PVP solution and AA solution was mixed in the ratio of 1:3 by weight, respectively. Platinum chloride $\left(\mathrm{PtCl}_{2}, 99.9 \%\right.$, Sigma Aldrich) was dissolved in a mixture of water and ethanol. This solution contained $3.8 \mathrm{wt}$. \% of platinum chloride with respect to aluminum acetate. The solution was mixed overnight at $50 \circ \mathrm{C}$. Then the solution was electrospun at a flow rate of $2 \mu \mathrm{l} / \mathrm{min}$ and an electric field of $1 \mathrm{kV} / \mathrm{cm}$. The sample was placed in a vacuum oven at room temperature for 5 hours to remove trapped solvents. The electrospun nanofibers were calcined to $600 \circ \mathrm{C}$ for 4 hours to obtain $\mathrm{PtO} / \mathrm{Al}_{2} \mathrm{O}_{3}$. Similar to Figure 3 for $\mathrm{PdO} / \mathrm{Al}_{2} \mathrm{O}_{3}$, the TGA analysis of $\mathrm{PtO} / \mathrm{Al}_{2} \mathrm{O}_{3}$ showed significant mass loss occurred as the temperature was ramped up to $450{ }^{\circ} \mathrm{C}$. Above $450{ }^{\circ} \mathrm{C}$ the sample mass became constant, indicating that the organic materials (PVP, ethanol, acetate group) had degraded and the volatile components had evaporated. Hence, the fibers calcined to $600{ }^{\circ} \mathrm{C}$ were relatively pure $\mathrm{PtO} / \mathrm{Al}_{2} \mathrm{O}_{3}$ and free of $\mathrm{PVP}$ and residual solvents.

Figure $7 \mathrm{a}$ shows scanning electron micrographs of $\mathrm{PtCl}_{2} /$ Aluminum Acetate/ PVP composite nanofibers. From Figure $7 \mathrm{~b}$, the average fiber diameters of $\mathrm{PtO} / \mathrm{Al}_{2} \mathrm{O}_{3}$ were in the range of 35-65 nm. After these composite nanofibers were calcined to $600{ }^{\circ} \mathrm{C}$, they were converted to $\mathrm{PtO} / \mathrm{Al}_{2} \mathrm{O}_{3}$. Figure 8 shows a sample TEM image of $\mathrm{PtO} / \mathrm{Al}_{2} \mathrm{O}_{3}$ of $\mathrm{PtO}$ nanoparticles on the alumina nanofiber. From the TEM images the average particle size of 100 measurements of the $\mathrm{PtO}$ nanoparticles on the $\mathrm{Al}_{2} \mathrm{O}_{3}$ nanofiber was calculated to be about $2.87 \pm 0.82 \mathrm{~nm}$.

The length weighted log-normal frequency fiber diameter distributions for $\mathrm{PtO} / \mathrm{Al}_{2} \mathrm{O}_{3}$ are shown in Figure 11 with average fiber diameter of $\overline{x_{g}}=53.05 \mathrm{~nm}$ and standard deviation of $\sigma_{g}=1.53$ for the log-normal distribution.
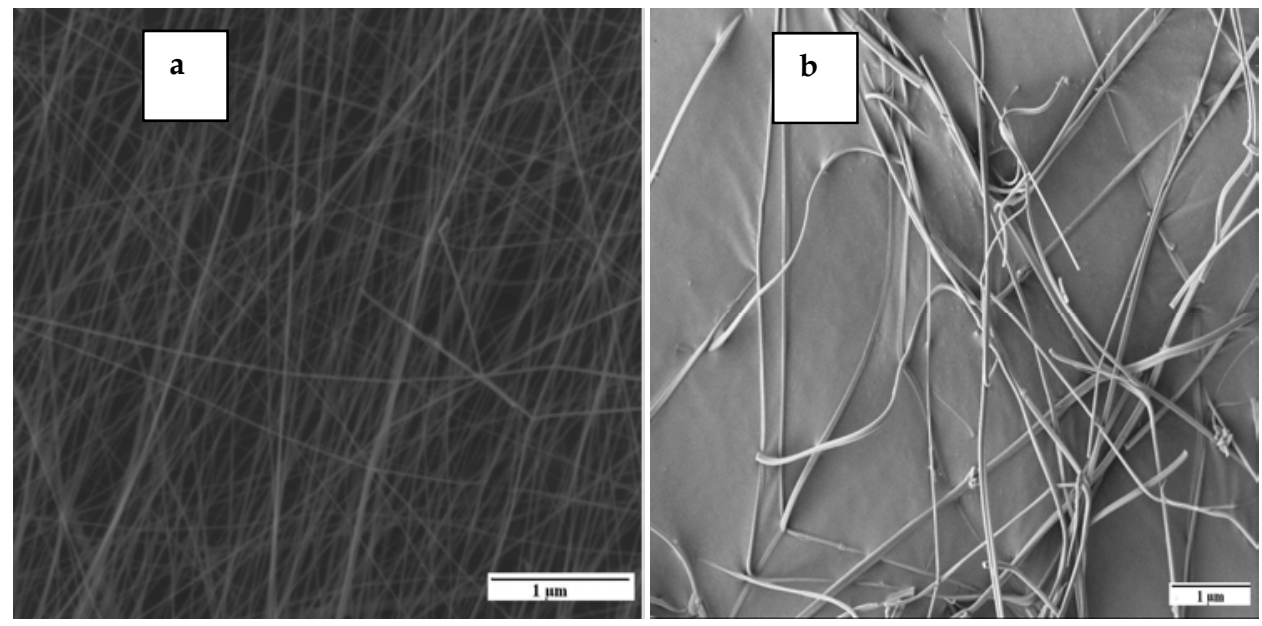

Fig. 7. Scanning electron micrographs of (a) $\mathrm{PtCl}_{2}$ / Aluminum Acetate/ PVP composite nanofibers (b) $\mathrm{PtO} / \mathrm{Al}_{2} \mathrm{O}_{3}$ nanofibers. 


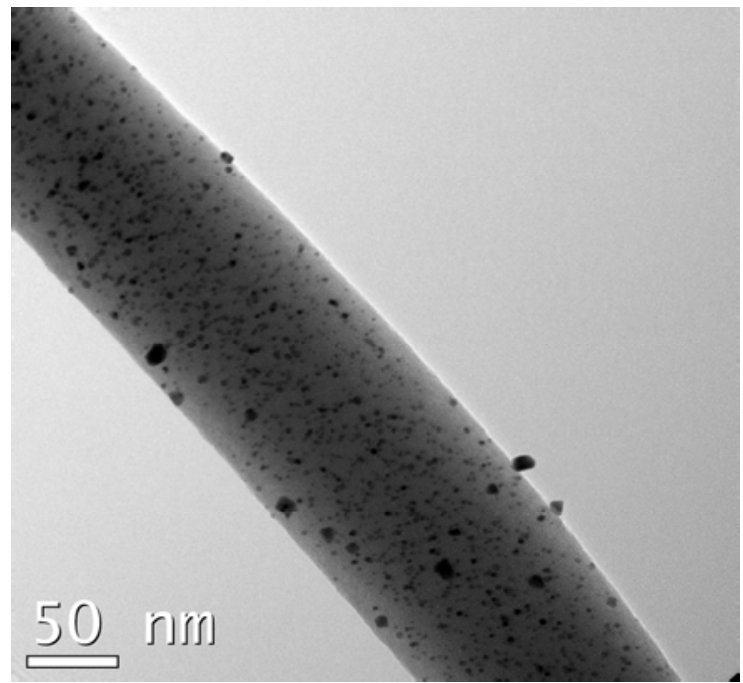

Fig. 8. Transmission electron micrographs of $\mathrm{PtO} / \mathrm{Al}_{2} \mathrm{O}_{3}$ nanofibers.

\section{Frequency Distribution vs Fiber Diameter}

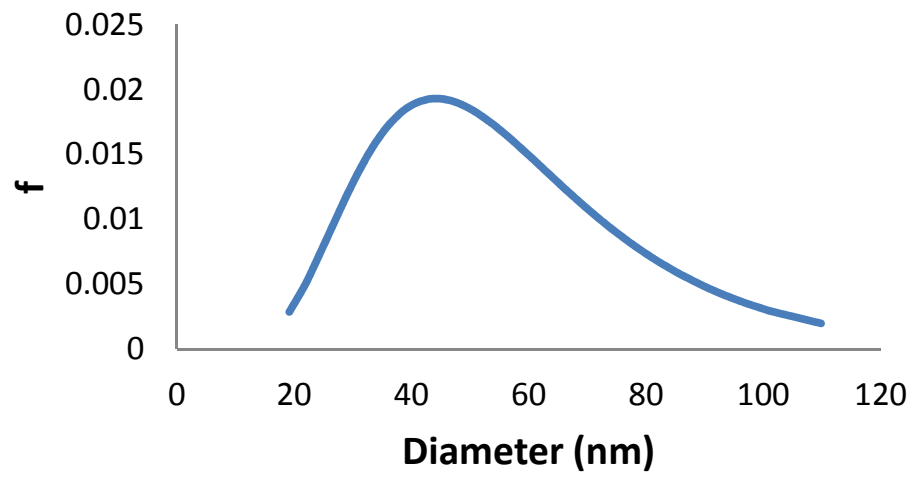

Fig. 9. Length weighted log-normal frequency distribution of $\mathrm{PtO} / \mathrm{Al}_{2} \mathrm{O}_{3}$ fiber diameters. 


\subsection{Electrospinning of rhodium incorporated alumina nanofibers}

9 wt \% PVP solution and AA precursor were added in the ratio of 1:4 by weight, respectively. Rhodium chloride $\left(\mathrm{RhCl}_{3}, 99.9 \%\right.$, Sigma Aldrich) was dissolved in ethanol in the ratio of $3.7 \mathrm{wt} \%$ of rhodium chloride respect to the aluminum acetate. This solution was mixed overnight at the $50{ }^{\circ} \mathrm{C}$. Using the rotating drum collector electrospinning setup, nanofiber mat was produced with a flow rate flow rate of $2 \mu \mathrm{l} / \mathrm{min}$ and an electric field of 1 $\mathrm{kV} / \mathrm{cm}$. The nanofibers were calcined at $600^{\circ} \mathrm{C}$ for 4 hrs to form $\mathrm{Rh}_{2} \mathrm{O}_{3} / \mathrm{Al}_{2} \mathrm{O}_{3}$ nanofibers.

The TGA analysis of $\mathrm{Rh}_{2} \mathrm{O}_{3} / \mathrm{Al}_{2} \mathrm{O}_{3}$ precursor fibers, similar to the TGA analysis of $\mathrm{PdO} / \mathrm{Al}_{2} \mathrm{O}_{3}$ in Figure 3, showed significant mass loss as the temperature ramped up to 450 ${ }^{\circ} \mathrm{C}$. Above $450{ }^{\circ} \mathrm{C}$, the sample mass became constant, indicating degradation of the PVP and evaporation of volatiles.

Figure 10(a) shows SEM images of $\mathrm{RhCl}_{3}$ / Aluminum Acetate/ PVP composite nanofibers. After these composite nanofibers were calcined to $600{ }^{\circ} \mathrm{C}$, they were converted to $\mathrm{Rh}_{2} \mathrm{O}_{3} / \mathrm{Al}_{2} \mathrm{O}_{3}$ (Figure 10b). Figure 11 shows an example TEM image of $\mathrm{Al}_{2} \mathrm{O}_{3}$ fibers with the $\mathrm{Rh}_{2} \mathrm{O}_{3}$ nanoparticles on the nanofiber. The average particle size of the $\mathrm{Rh}_{2} \mathrm{O}_{3}$ nanoparticles was $1.16 \pm 0.35 \mathrm{~nm}$.

The length weighted log-normal frequency fiber diameter distribution for $\mathrm{Rh}_{2} \mathrm{O}_{3} / \mathrm{Al}_{2} \mathrm{O}_{3}$ is shown in Figure 12. The average fiber diameter is $\overline{x_{g}}=61.57 \mathrm{~nm}$ and the standard deviation is $\sigma_{g}=1.33$ for the log-normal distribution.
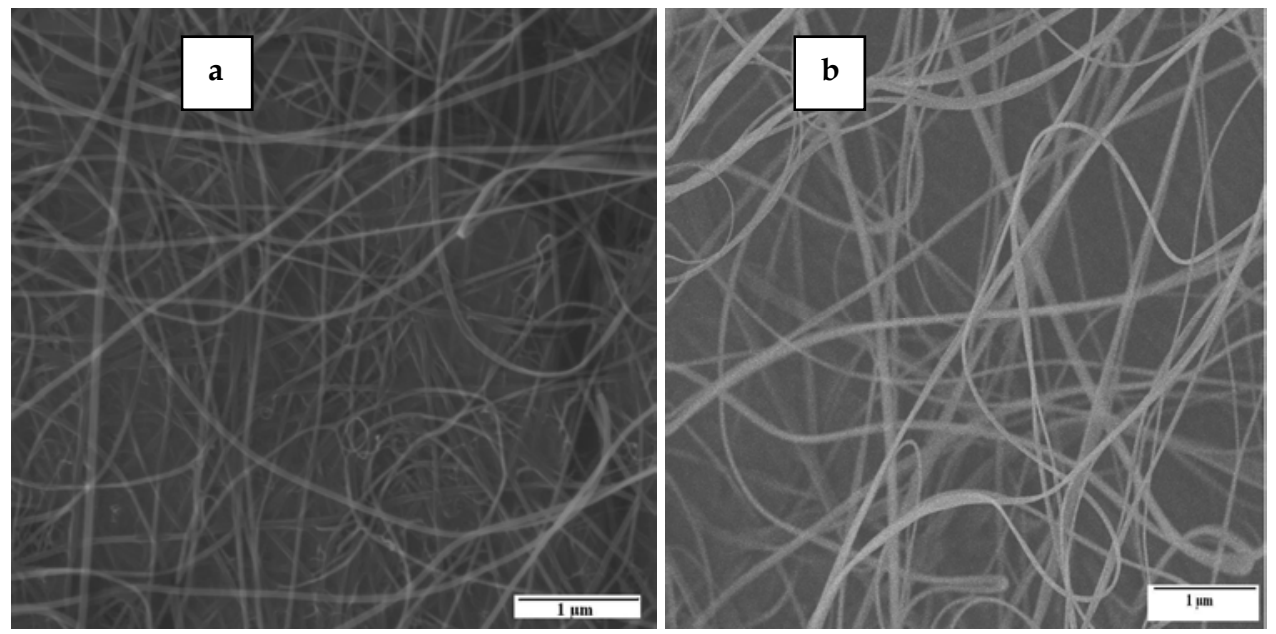

Fig. 10. (a) Scanning electron micrographs of of $\mathrm{RhCl}_{3}$ / Aluminum Acetate/ PVP composite nanofibers (b) $\mathrm{Rh}_{2} \mathrm{O}_{3} / \mathrm{Al}_{2} \mathrm{O}_{3}$ nanofibers. 


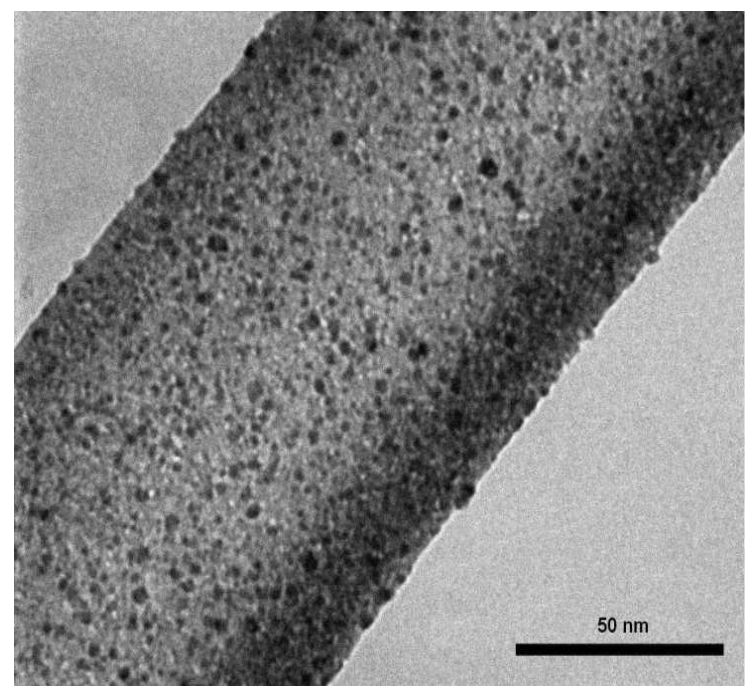

Fig. 11. Transmission electron micrograph of $\mathrm{Rh}_{2} \mathrm{O}_{3} / \mathrm{Al}_{2} \mathrm{O}_{3}$ nanofibers.

\section{Frequency Distribution vs Fiber Diameter}

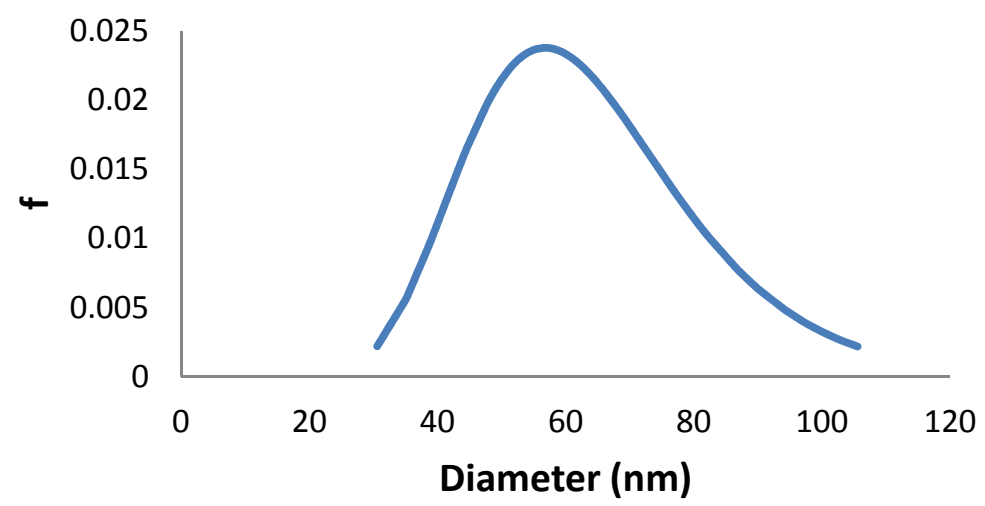

Fig. 12. Length weighted log-normal fiber diameter frequency distribution of of $\mathrm{Rh}_{2} \mathrm{O}_{3} / \mathrm{Al}_{2} \mathrm{O}_{3}$ nanofibers. 


\subsection{Formation of nanofiber based filter media}

Filter media were prepared by vacuum molding an aqueous slurries of fibers and binder. The vacuum molding apparatus consists of a mixing tank, filter mold, collection tank and vacuum pump. The slurry was prepared using a mixture of microfibers, ceramic nanofibers, corn starch and alumina binder in water. Diluted acid was added to maintain the slurry at a $\mathrm{pH} \sim 6.0$ and starch was added to enhance the binding capability of the binder and fibers. The slurry was mixed overnight using a stirrer to obtain a uniform dispersion of materials. It was poured into the mixing tank and agitated by bubbling into the bottom of the tank. The Plexiglas mold was located at the bottom of the mixing tank. The mold had an internal diameter of $2.3 \mathrm{~cm}$, equal to the diameter of the filter. The bottom of the mold had a fine steel wire mesh to capture the fibers. A vacuum was applied to the collection tank. A hose from the collection tank to the underside of the mold transferred the vacuum pressure to the mold to pull the slurry from the mixing tank through the steel mesh. The fibers were retained on the steel mesh forming a wet fibrous filter cake. The wet cake was heated to dry the cake and to thermally set the binder.

The slurry in the mixing tank consisted of $4 \mathrm{~L}$ of water, $0.5 \mathrm{~g}$ of alumina microfibers (SAFFIL HA, Thermal Ceramics), $0.05 \mathrm{~g}$ catalytic fibers, $0.02 \mathrm{~g}$ corn starch, $1 \mathrm{~mL}$ alumina binder (alumina rigidizer, Zircar Ceramics) and about 20 drops of dilute $\mathrm{H}_{2} \mathrm{SO}_{4}$ acid. The slurry was stirred for 8 hours before it was vacuum molded at 5 psi to form a filter wet filter cake. The wet cake was dried at $120{ }^{\circ} \mathrm{C}$ for 2 hours to remove moisture and calcined to $600 \circ \mathrm{C}$ for 4 hours to set the binder. The filter disk was heated at $400{ }^{\circ} \mathrm{C}$ with hydrogen gas $\left(20 \% \mathrm{H}_{2}, 80\right.$ $\% \mathrm{~N}_{2}$ ) for 4 hours to convert the precious metal oxides to their native metal form.

Figure 13 is a sample SEM image of the alumina microfibers. The average fiber diameter range determined by log-normal frequency distribution (Figure 14) was calculated to be $\overline{x_{g}}=$ $3.20 \mu \mathrm{m}$ and the standard deviation was $\sigma_{\mathrm{g}}=1.29$ for the log-normal distribution. Alumina microfibers were used to structurally and functionally support the catalytic fibers because they can withstand high temperatures and they have a similar coefficient of expansion in comparison to the catalytic nanofibers.

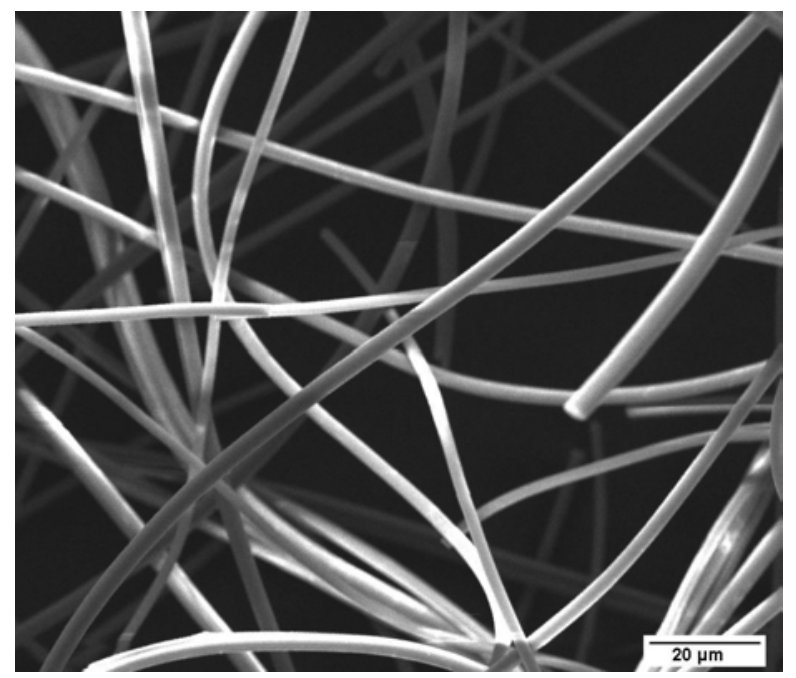

Fig. 13. Scanning electron micrographs of $\mathrm{Al}_{2} \mathrm{O}_{3}$ microfibers. 
Figure 15 (a) shows picture of a catalytic filter having diameter of $2.3 \mathrm{~cm}$ and height of 1.5 $\mathrm{cm}$. The filter can be molded to the desired shape and dimensions using molds and meshes with the desired diameter. Figure 15 (b) are scanning electron micrographs of sections of catalytic filters. The nanofibers are entrapped by the large microfibers. This structure results in higher capture efficiencies and quality factor for a very small increase in pressure drop in comparison to a filter with only microfibers (Srinivasan, 2005).

\section{Frequency Distribution vs Fiber Diameter}

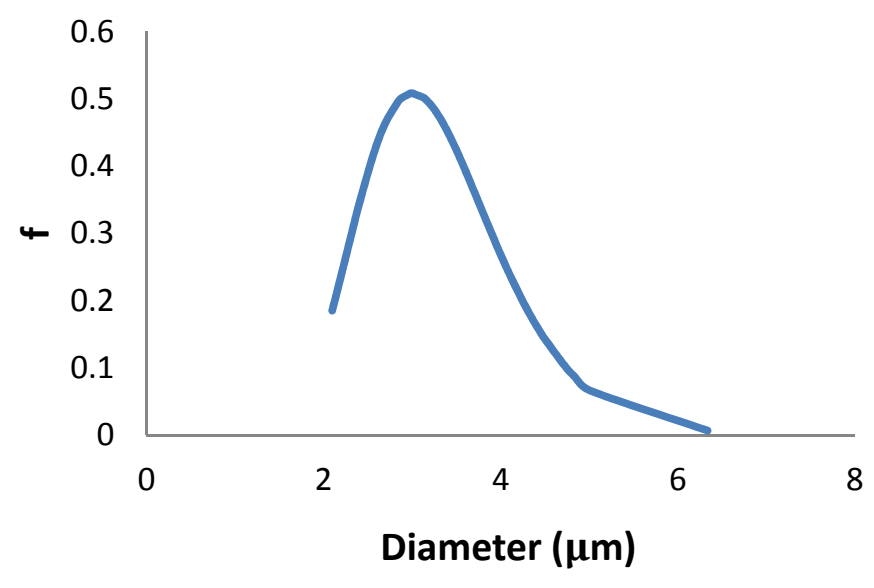

Fig. 14. Length weighted log-normal frequency of fiber diameter of $\mathrm{Al}_{2} \mathrm{O}_{3}$ microfibers.
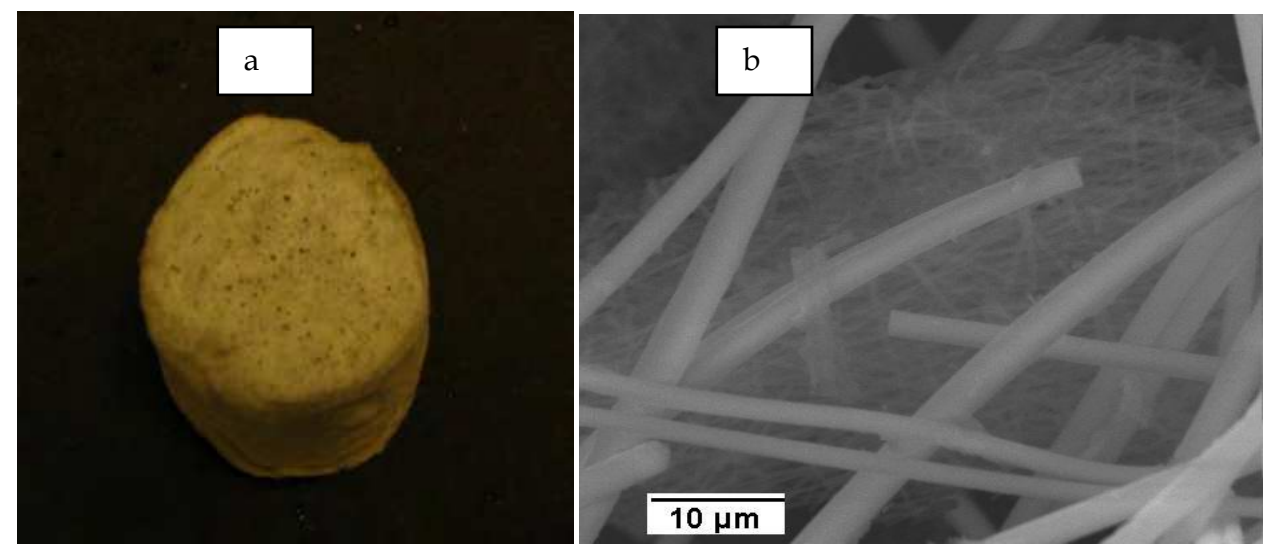

Fig. 15. (a) Disk shaped catalytic filter approximately $2.3 \mathrm{~cm}$ in diameter and $1.2 \mathrm{~cm}$ thick. (b) SEM image of nanofibers mixed among microfibers in the catalytic filter. 


\subsection{Characterization of filter media}

The catalytic filters were characterized for porosity, permeability and hardness.

\subsubsection{Porosity}

Porosity is a 3-dimensional measurement of the void volume of a filter material. Porosity is defined as the ratio of the volume of all of the pores of a material to the volume of the filter and is one of the parameters that describes the structure of the filter material. A special made pycnometer was used to measure the bulk porosity of the filter media by a gas expansion method. The pycnometer consists of two chambers, one (with a removable gastight lid) and the second chamber of a fixed, known internal volume - referred to as the reference volume or added volume. The device also comprises a valve to admit a gas under pressure to the second chamber, a pressure measuring device and a valved vent from the second chamber.

The porosities of three of the disk shaped catalytic filters are listed in Table 1. Each listed porosity is the average of three filters of the same type. The accuracy of the special made pycnometer is at best \pm 0.01 .

\begin{tabular}{|l|l|}
\hline Type of catalytic filter & Porosity \pm 0.01 \\
\hline $\mathrm{Pd} / \mathrm{Al}_{2} \mathrm{O}_{3}$ & 0.97 \\
\hline $\mathrm{Pt} / \mathrm{Al}_{2} \mathrm{O}_{3}$ & 0.97 \\
\hline $\mathrm{Rh} / \mathrm{Al}_{2} \mathrm{O}_{3}$ & 0.96 \\
\hline
\end{tabular}

Table 1. Porosity of the catalytic filters.

\subsubsection{Permeability}

Permeability is defined as the volume of a fluid that will move across a known area of filter media at a constant pressure drop. It is used to describe how easily a fluid flows through a material and is measured by a Frazier Air Permeability tester (Frazier Prevision Instrument Co.) modified to hold the disk shaped filters. The Frazier test is based on Darcy's law which relates the pressure drop to flow through a packed bed with the permeability coefficient as given by Equation (4):

$$
\frac{k}{\mu}\left(\frac{P_{O}-P_{L}}{L}\right)=\frac{Q}{A}
$$

where $\mathrm{k}=$ Permeability in $\mathrm{m}^{2}$

$\mathrm{P}_{\mathrm{o}}=$ Initial pressure, in $\mathrm{Pa}$

$\mathrm{P}_{\mathrm{L}}=$ Final pressure, in $\mathrm{Pa}$

$\mathrm{L}=$ Thickness of media, in $\mathrm{m}$

$\mathrm{Q}=$ Volumetric flow rate, in $\mathrm{m}^{3} / \mathrm{s}$

$\mu=$ Kinematic viscosity, in Ns $/ \mathrm{m}^{2}$

$\mathrm{A}=$ Area, in $\mathrm{m}^{2}$

Table 2 lists the permeabilities of the catalytic filters for measurements done in triplicate for each type of catalytic filter. 


\begin{tabular}{|l|l|}
\hline Type of catalytic filter & Permeability $\left(\mathrm{m}^{2}\right)$ \\
\hline $\mathrm{Pd} / \mathrm{Al}_{2} \mathrm{O}_{3}$ & $1.25 \pm 0.05^{*} 10^{-11}$ \\
\hline $\mathrm{Pt} / \mathrm{Al}_{2} \mathrm{O}_{3}$ & $1.15 \pm 0.08^{*} 10^{-11}$ \\
\hline $\mathrm{Rh} / \mathrm{Al}_{2} \mathrm{O}_{3}$ & $1.4 \pm 0.1^{*} 10^{-11}$ \\
\hline
\end{tabular}

Table 2. Permeability of the catalytic filters.

\subsubsection{Hardness}

A durometer (Rex Gauge Co. Model 1600 Type O) was used to measure the hardness of the filter. Type $\mathrm{O}$ durometers are used for very soft elastomers, textile windings, soft granular materials (Rex Durometers, 2006) and is suitable for measuring the hardness of fibrous filters. In this durometer, the load deflection curve is a straight line where 100 durometer $\mathrm{O}$ points equals 822 grams and zero durometer $\mathrm{O}$ points equals $56 \mathrm{~g}$. The durometer was pressed down and held in a vertical position till the entire foot was in contact with the filter. The dial hand gave the durometer reading. The reading after 15 seconds was also noted while maintaining firm contact of the durometer foot against the filter to make sure that the value was consistent and there was no creep or cold-flow of the filter. The hardness values of the catalytic filters are given in Table 3, as the average of triplicate measurements.

\begin{tabular}{|l|l|l|}
\hline Type of catalytic filter & Durometer O Points & Load(g) \\
\hline $\mathrm{Pd} / \mathrm{Al}_{2} \mathrm{O}_{3}$ & $10 \pm 2$ & 110 \\
\hline $\mathrm{Pt} / \mathrm{Al}_{2} \mathrm{O}_{3}$ & $14 \pm 1$ & 140 \\
\hline $\mathrm{Rh} / \mathrm{Al}_{2} \mathrm{O}_{3}$ & $13 \pm 1$ & 120 \\
\hline
\end{tabular}

Table 3. Hardness of the catalytic filters

\subsection{Reaction test setup}

The reaction test setup was constructed to test the activity of the catalytic filter when challenged with $\mathrm{NO}$ and $\mathrm{CO}$ gases. $\mathrm{He}, \mathrm{CO}$ and $\mathrm{NO}$ were forced through the catalytic filter cell with controlled flow rates using mass flow controllers. To increase the velocity and to maintain the stoichiometry of $\mathrm{NO}$ and $\mathrm{CO}, \mathrm{He}$ was used as the carrier gas. In the construction of the filter cell, two stainless steel cylindrical blocks were machined with a central hole of diameter $2.3 \mathrm{~cm}$ and three holes in the corners for screwing the two parts together. These two parts were bolted together. A gasket made of ceramic fibers was used for sealing the reactor. Bottom and top parts of the reactor were connected with $1 / 8^{\prime \prime}$ stainless steel tubing to the rest of the setup (Figure 16). To control the reactor temperature, the reactor was wrapped with heating tape connected to a temperature controller and insulated. 
The pressure drop across the reactor was measured using a pressure transducer. The concentration of the inlet and the outlet gases were measured using a gas chromatograph (GC). The GC was connected to a computer where the peaks of the gases were displayed and their respective concentrations were calculated. Figure 17 shows the flow diagram of the reactor setup.
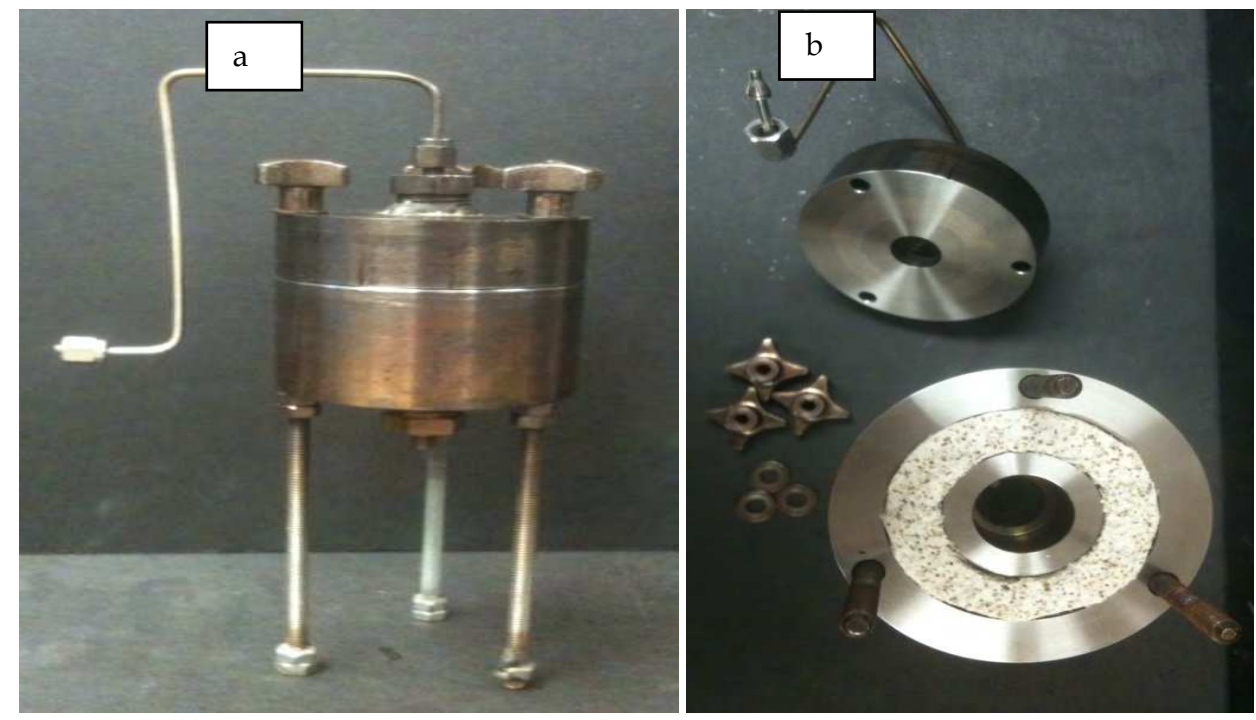

Fig. 16. (a) Reactor (b) Internal view of the reactor and screws.

The ceramic filter medium was positioned in the filter holder for measuring its activity. The gases were continuously flowed from the bottom of the reactor and exhausted from the top. The inlet concentration and the exhaust concentration were monitored by the GC. The temperature of the reactor was gradually increased to observe the light-off temperature of the NO and CO gases. The concentration profile of the inlet and outlet gases was obtained with respect to different temperatures. The maximum temperature the setup was taken to was $450{ }^{\circ} \mathrm{C}$.

For the $\mathrm{Pd} / \mathrm{Al}_{2} \mathrm{O}_{3}$ (Figure 18) catalytic filter which contained $0.05 \mathrm{~g}$ of the $\mathrm{PdO} / \mathrm{Al}_{2} \mathrm{O}_{3}$ nanofibers the decomposition temperature of $\mathrm{NO}$ was $350{ }^{\circ} \mathrm{C}$. In the case of $\mathrm{Pt} / \mathrm{Al}_{2} \mathrm{O}_{3}$ (Figure 19) the filter contained $0.05 \mathrm{~g}$ of $\mathrm{PtO} / \mathrm{Al}_{2} \mathrm{O}_{3}$ nanofibers and the decomposition temperature of $\mathrm{NO}$ was $325{ }^{\circ} \mathrm{C}$. The $\mathrm{Rh} / \mathrm{Al}_{2} \mathrm{O}_{3}$ (Figure 20) filter decomposed $\mathrm{NO}$ at a much lower temperature of $250{ }^{\circ} \mathrm{C}$. This is because $\mathrm{NO}$ readily dissociates on $\mathrm{Rh}\{111\}$ and $\mathrm{N}_{2}$ is adsorbed from the Rh surfaces from 200 to $300{ }^{\circ} \mathrm{C}$ (Lambert \& Bridge, 1984; Hendrickx \& Nieuwenhuys, 1986). On the other hand, Pt and Pd are good for oxidation reactions and but are less able to dissociate NO than Rh (Thomas \& Thomas, 1997). 


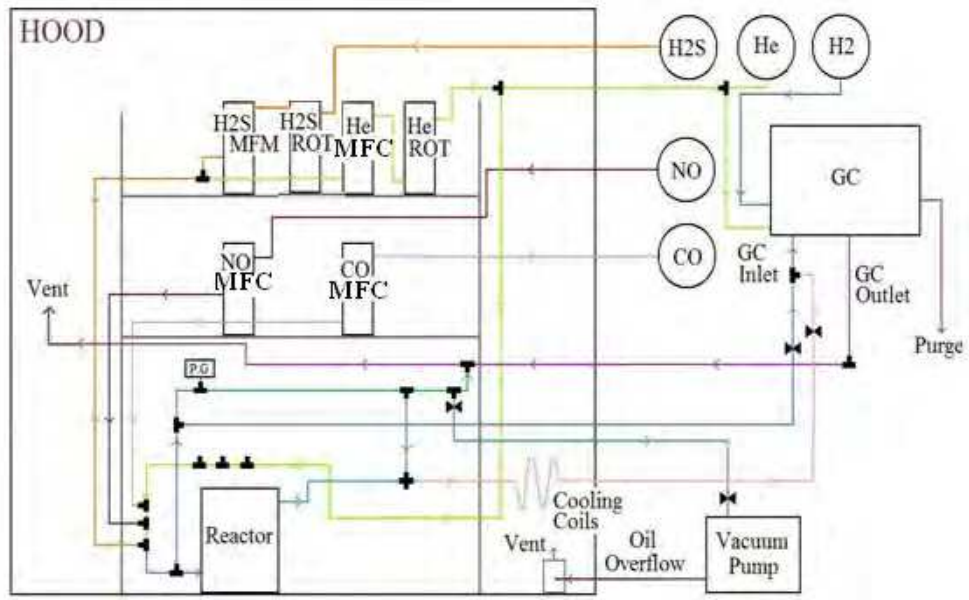

MFC - Mass Flow Controller; MFM - Mass Flow Meter; ROT - Rotameter;

P.G. - Pressure Gage; GC - Gas Chromatograph

Fig. 17. Flow diagram of the reactor setup.

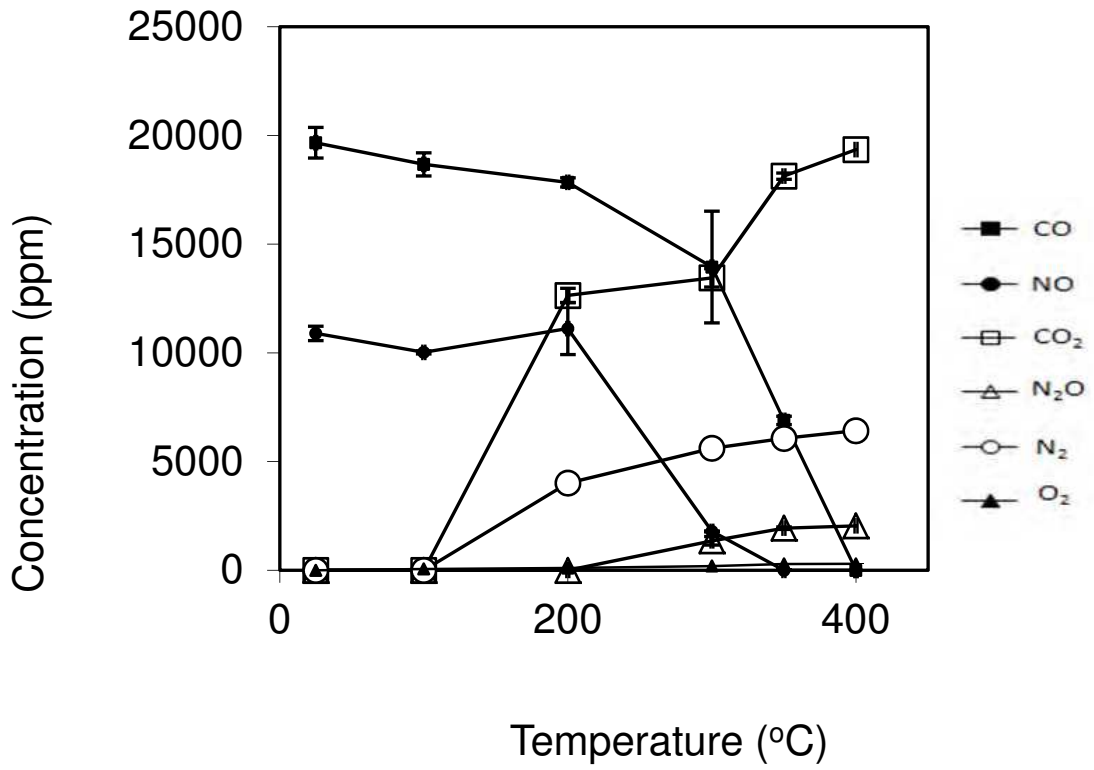

Fig. 18. Concentration vs. temperature for the reaction over $0.05 \mathrm{~g}$ of $\mathrm{Pd} / \mathrm{Al}_{2} \mathrm{O}_{3}$. 


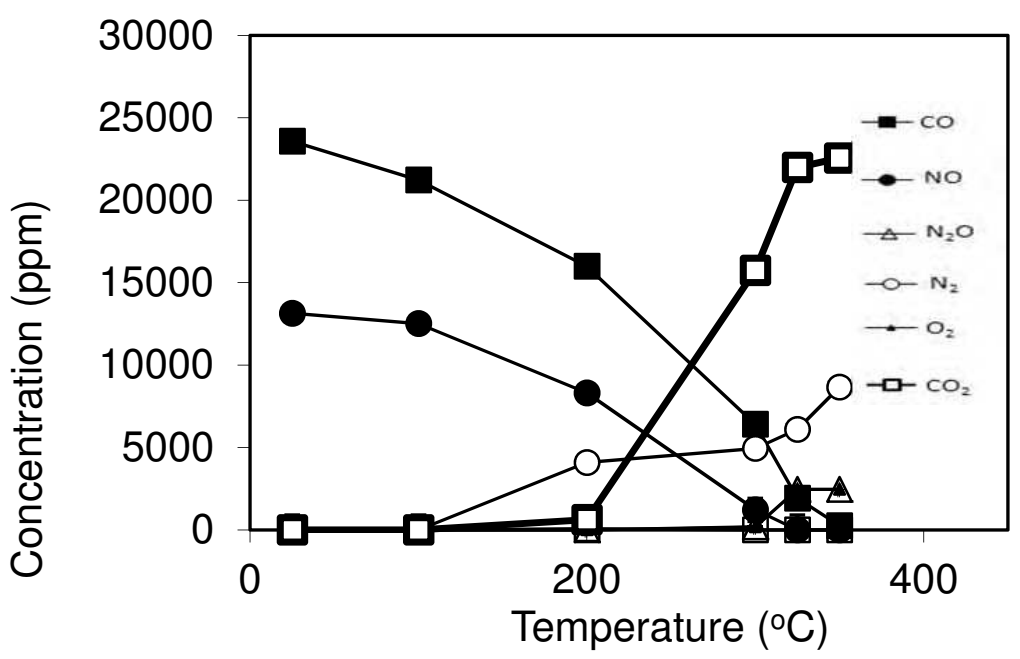

Fig. 19. Concentration vs. temperature for the reaction over $0.05 \mathrm{~g}$ of $\mathrm{Pt} / \mathrm{Al}_{2} \mathrm{O}_{3}$.

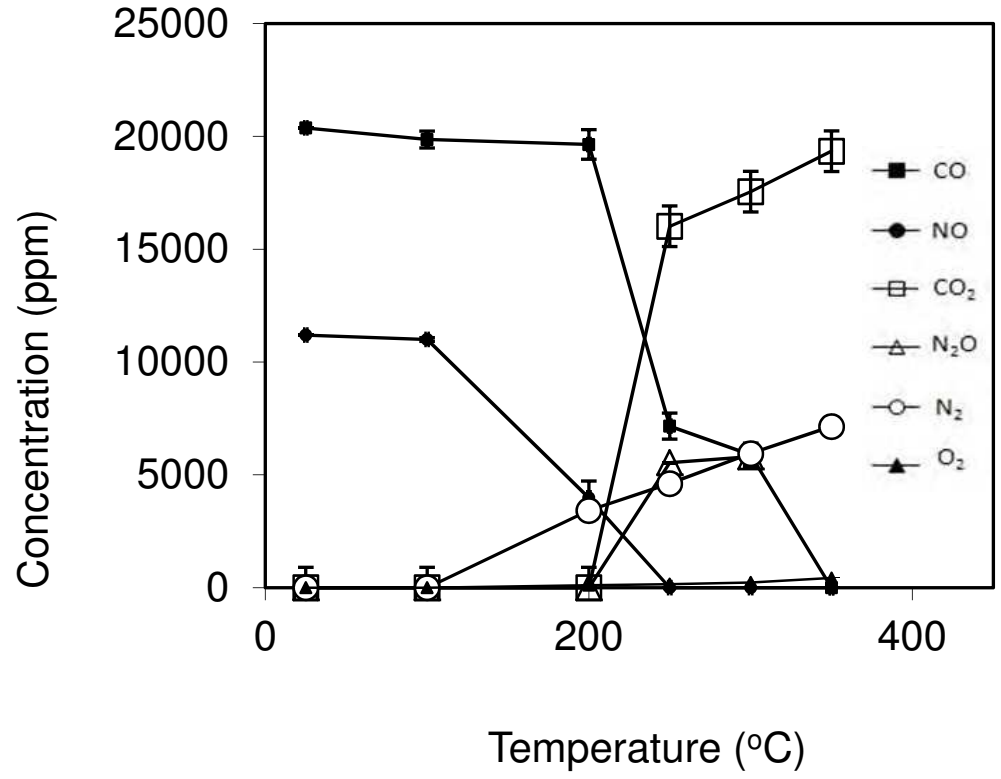

Fig. 20. Concentration vs. temperature for the reaction over $0.05 \mathrm{~g}$ of $\mathrm{Rh} / \mathrm{Al}_{2} \mathrm{O}_{3}$. 


\section{Conclusion}

In this research, the noble metals (palladium, platinum and rhodium) have been incorporated into alumina nanofiber support by sol gel processing and electrospinning techniques. The diameter of the nanofibers and the particle sizes of the noble metals are summarized in Table 4.

\begin{tabular}{|l|l|l|}
\hline Material & Fiber Diameter $(\mathrm{nm})$ & Catalyst Particle Diameter $(\mathrm{nm})$ \\
\hline $\mathrm{PdO} / \mathrm{Al}_{2} \mathrm{O}_{3}$ & $40-70$ & $2.43 \pm 0.70$ \\
\hline $\mathrm{PtO} / \mathrm{Al}_{2} \mathrm{O}_{3}$ & $35-65$ & $2.87 \pm 0.82$ \\
\hline $\mathrm{Rh}_{2} \mathrm{O}_{3} / \mathrm{Al}_{2} \mathrm{O}_{3}$ & $50-80$ & $1.16 \pm 0.35$ \\
\hline
\end{tabular}

Table 4. Diameter of the nanofibers and catalyst particles.

These nanofibers were mixed with alumina microfibers to form a filter using vacuum molding. The catalytic filter was reduced under flowing hydrogen to reduce the noble metal oxide into their native metal form. This filter was tested in a stream of $\mathrm{NO}$ and $\mathrm{CO}$. The NO gas was completely decomposed in the temperature range $225 \sim 400{ }^{\circ} \mathrm{C}$ depending on the type and amount of catalyst and reaction conditions. Nitrogen, carbon dioxide, and nitrous oxide gases were detected as reaction products. The electrospinning solutions for fabricating the catalyst supporting nanofibers were optimized by varying the ratio of aluminum acetate precursor solution and carrier polymer solutions to obtain maximum yield of ceramic nanofibers.

\section{References}

Ahn, YC; Park, SK; Kim, GT; Hwang, YJ; Lee, CG; Shin, HS; Lee, JK. (2006) Development of high efficiency nanofilters made of nanofibers. Current Applied Physics. Vol. 6, pp. 1030-1035.

Armor JN. (1994) Environmental Catalysis. American Chemical Society, Washington DC.

Ayral, A; Droguet, JC. (1989). Alumina powders via a controlled precipitation of aluminum acetate. Journal of Materials Research. Vol. 4, pp. 967-971.

Barhate, RS; Ramakrishna, S. (2007) Nanofibrous filtering media: Filtration problems and solutions from tiny materials. Journal of Membrane Science. Vol. 296, pp. 1-8.

Degobert, P; Marshall, N. (1995) Society of Automotive Engineers. Automobiles and Pollution. s.l. : Editions TECHNIP.

Doshi J; Reneker DH.(1995) Electrospinning process and applications of electrospun fibers. Journal of Electrostatics.Vol. 35, pp. 151-160 .

Dosunmu, OO; Chase. GG; Kataphinan, W; Reneker, DH. (2006) Electrospinning of polymer nanofibres from multiple jets on a porous tubular surface. Nanotechnology.Vol. 17, pp. 1123-1127.

EPA. National Summary of Nitrogen Oxides Emissions, May 10, 2010, Available from $<: / /$ www.epa.gov/air/emissions/nox.htm>

Esumi, K; Itakura, T; Torigoe, K.(1994) Preparation of organo palladium sols from palladium complexes in various alcohols. Colloids and Surfaces A: Physicochemical and Engineering Aspects, Vol. 82, pp. 111-113.

Filatov, Y; Budyka, A; Kirichenko, V; (2007). Electrospinning of Micro- and Nanofibers Fundamentals and applications in separation and filtration processes. Begell House,Inc, Connecticut. 
Gai, PL; Roper, R; White, MG. (2002) Recent advances in nanocatalysis research. Current Opinion in Solid State and Materials Science. Vol. 6, pp. 401-406.

Gniewek, A; Ziolkowski, JJ; Trzeciak, AM; Zawadzki, M; Grabowska, H; Wrzyszcz, J. (2008) Palladium nanoparticles supported on alumina-based oxides as heterogeneous catalysts of the Suzuki-Miyaura reaction. Journal of Catalysis. Vol. 254, pp. 121-130.

Haagen-Smit; AJ. (1970) A Lesson from the Smog Capital of the World. Proceedings of the National Academy of Sciences. Vol. 67, pp. 887-897.

Heck RM, Farrauto RJ. Catalytic Air Pollution Control Commercial Technology. New Jersey: John Wiley \& Sons, Inc., 1995.

Heidenreich; S, Nacken; M, Hackel; M, Schaub; G. (2008) Catalytic filter elements for combined particle separation and nitrogen oxides removal from gas streams. Powder Technology. Vol. 180, pp. 86- 90.

Hendrickx; HACM, Nieuwenhuys; BE. (1986) Surface structure effects in the adsorption and desorption of nitric oxide on rhodium. Surface Science. Vol. 175, pp. 185-196 .

Hermans, S; Raja, R; Thomas, JM; Johnson, BFG; Sankar G, Gleeson D. (2001) Solvent-Free, Low-Temperature, Selective Hydrogenation of Polyenes using a Bimetallic Nanoparticle Ru - Sn Catalyst. Angewandte Chemie International Edition. Vol. 40, pp. 1211-1215.

Hirai, H; Chawanya, H; Toshima, N. (1985) Colloidal palladium protected with poly(Nvinyl-2-pyrrolidone) for selective hydrogenation of cyclopentadiene. Reactive Polymers. 1985, Vol. 3, pp. 127-141.

Huang, ZM; Zhang, YZ; Kotaki, M; Ramakrishna, S. A review on polymer nanofibers by electrospinning and their applications in nanocomposites. Composites Science and Technology. 2003, Vol. 63, pp. 2223-2253.

Lambert, RM; Bridge, ME. (1984). Chemistry and Physics of Solid Surfaces and Heterogeneous Catalysis. [ed.] Woodruff DP King DA. Elsevier, Amsterdam. Vol. 3, pp. 83-101.

Li, D; Xia, Y (2004). Electrospinning of Nanofibers: Reinventing the Wheel? Advanced Materials. Vol. 16, pp. 1151-1170.

Luo, C; Zhang, Y; Wang, Y. (2005) Palladium nanoparticles in poly(ethyleneglycol): the efficient and recyclable catalyst for Heck reaction. Journal of Molecular Catalysis A: Chemical. Vol. 229, pp. 7-12.

Meulenbelt; J. Nitrogen and nitrogen oxides. (2007). Medicine, Vol. 35, pp. 638

Narayanan; R, El-Sayed; MA. Effect of colloidal nanocatalysis on the metallic nanoparticle shape: The Suzuki Reaction. Langmuir. 2005, Vol. 21, pp 2027-2033.

Park; C, Baker; RTK. (1998) Catalytic behavior of graphite nanofiber supported nickel particles. The influence of the nanofiber structure. Journal of Physical Chemistry B. Vol. 102, pp. 5168-5177.

Park; SJ, Bhargava; S, Bender; ET, Chase; GG, Ramsier; RD. (2008) Palladium nanoparticles supported by alumina nanofibers synthesized by electrospinning. Journal of Materials Research. Vol. 23, pp. 1193-1196.

Patel; C, Li; S, Wang; C, Zhang; W,Wei; Y. (2007) Electrospinning of porous silica nanofibers containing silver nanoparticles for catalytic applications. Chemistry of materials. Vol. 19, pp. 1231-1238.

Patterson; DJ, Henein; NA. (1972) Emissions from Combustion Engines and their Control. Ann Arbor : Ann Arbor Science Publishers, Inc.

Graham; K, Ouyang; M, Raether; T, Grafe; T, McDonald; B, Knauf; P. (2002) Polymeric Nanofibers in Air Filtration Applications. Fifteenth Annual Technical Conference \& Expo of the American Filtration \& Separations Society.Galveston. 
Qian; XF, Yin; J, Feng; S, Liu; SH, Zhu; ZK. (2001). Preparation and characterization of polyvinylpyrrolidone films containing silver sulfide nanoparticles. Journal of Materials Chemistry. Vol. 11, pp. 2504-2506.

Raja; R, Khimyak; T, Thomas; JM, Hermans; S, Johnson; BFG. (2001) Single-Step, Highly Active, and Highly Selective Nanoparticle Catalysts for the Hydrogenation of Key Organic Compounds. Angewandte Chemie International Edition. Vol. 40, pp. 4638 - 4642.

Ramaseshan; R, Sundarrajan; S, Jose; R, Ramakrishna; S. (2007). Nanostructured ceramics by electrospinning. Journal of Applied Physics. Vol. 102, pp. 111101-111101-17.

Raub; JA, Nolf; MM, Hampson; NB. (2000). Carbon monoxide poisoning - a public health perspective. Toxicology. Vol. 145, pp. 1-14.

Research, BCC. April 10, 2011. Catalysts for Environmental and Energy Applications. Available from < http://bccresearch.com/report/catalysts-environment-energychm020c.html>

Rex Gauge Company, Inc. April 10, 2011. Available from $<$ http://www.rexgauge.com/content/tech_reference_guide>.

Schlogl; E, Hamid; SBA. (2004). Nanocatalysis: Mature science revisited or something really new? Angewandte Chemie International Edition. Vol. 43, pp. 1628 -1637.

Shelef; M, McCabe; RW. (2000). Twenty-five years after introduction of automotive catalysts: what next? Catalysis Today. Vol. 62, pp. 35-50.

Silver; RG, Sawyer; JE, Summers; JC. (1992). Catalytic Control of Air Pollution. American Chemical Society, New York.

Srinivasan; P. (2005). M.S. Thesis, Nanofiber incorporated glass fiber filter media, The University of Akron.

Sukigara; S, Gandhi; M, Ayutsede; J, Micklus; M, Ko; F. (2003). Regeneration of Bombyx mori silk by electrospinning - part 1: processing parameters and geometric properties. Polymer. Vol. 44, pp. 5721-5727.

Takashi; M, Masaru; H, Yuichi; I, Kyoko; KB, Nobuyuki; M, Makoto; T, Yuji; Y. (2005) Effect of noble metal particle size on the sulfur tolerance of monometallic $\mathrm{Pd}$ and Pt catalysts supported on high-silica USY zeolite. Applied Catalysis A. Vol. 286, pp.249-257.

Thomas; JM, Johnson; BFG, Raja; R, Sankar; G, Midgley; PA. (2004). High-Performance Nanocatalysts for Single-Step Hydrogenations. Accounts of Chemical Research. Vol. 36, pp. 20-30.

Thomas; JM, Thomas; WJ. (1997). Heterogeneous Catalysis. VCH Publishers Inc.,New York.

Tribolet P, Kiwi-Minsker L. Palladium on carbon nanofibers grown on metallic filters as novel structured catalyst. Catalysis Today. 2005, Vol. 105, pp. 337-343.

Tsai; PP, Gibson; HS, Gibson; P. (2002) Different electrostatic methods for making electret filters. Journal of Electrostatics. Vol. 54, pp. 333-341 .

Twigg; MV.(2007). Progress and future challenges in controlling automotive exhaust gas emissions. Applied Catalysis B: Environmental. Vol. 70, pp. 2-15.

Varabhas; JS, Chase; GG, Reneker; DH. (2008). Electrospun nanofibers from a porous hollow tube. Polymer.Vol. 49, pp. 4226-4229.

Wei; G, Ma; PX. (2004). Structure and properties of nano-hydroxyapatite/polymer composite scaffolds for bone tissue engineering. Journal of Biomaterials. Vol. 25, pp. 4749-4757.

Zhou; B, Hermans; S, Somorjai; GA. (2004). Nanotechnology in Catalysis: Roadmap to new catalyst systems: Palladium nanoparticles. American Chemical Society, Springer, New York. 


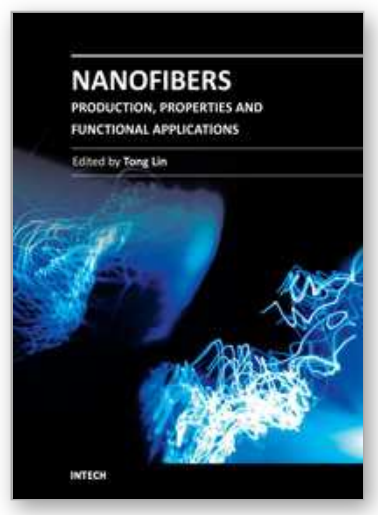

\author{
Nanofibers - Production, Properties and Functional Applications \\ Edited by Dr. Tong Lin
}

ISBN 978-953-307-420-7

Hard cover, 458 pages

Publisher InTech

Published online 14, November, 2011

Published in print edition November, 2011

As an important one-dimensional nanomaterial, nanofibers have extremely high specific surface area because of their small diameters, and nanofiber membranes are highly porous with excellent pore interconnectivity. These unique characteristics plus the functionalities from the materials themselves impart nanofibers with a number of novel properties for advanced applications. This book is a compilation of contributions made by experts who specialize in nanofibers. It provides an up-to-date coverage of in nanofiber preparation, properties and functional applications. I am deeply appreciative of all the authors and have no doubt that their contribution will be a useful resource for anyone associated with the discipline of nanofibers.

\title{
How to reference
}

In order to correctly reference this scholarly work, feel free to copy and paste the following:

Sneha Swaminathan and George Chase (2011). Electrospinning of Metal Doped Alumina Nanofibers for Catalyst Applications, Nanofibers - Production, Properties and Functional Applications, Dr. Tong Lin (Ed.), ISBN: 978-953-307-420-7, InTech, Available from: http://www.intechopen.com/books/nanofibers-productionproperties-and-functional-applications/electrospinning-of-metal-doped-alumina-nanofibers-for-catalystapplications

\section{INTECH}

open science | open minds

\section{InTech Europe}

University Campus STeP Ri

Slavka Krautzeka 83/A

51000 Rijeka, Croatia

Phone: +385 (51) 770447

Fax: +385 (51) 686166

www.intechopen.com

\section{InTech China}

Unit 405, Office Block, Hotel Equatorial Shanghai

No.65, Yan An Road (West), Shanghai, 200040, China

中国上海市延安西路65号上海国际贵都大饭店办公楼405单元

Phone: +86-21-62489820

Fax: +86-21-62489821 
(C) 2011 The Author(s). Licensee IntechOpen. This is an open access article distributed under the terms of the Creative Commons Attribution 3.0 License, which permits unrestricted use, distribution, and reproduction in any medium, provided the original work is properly cited. 